\title{
EFFECT OF DIETARY FAT ON OBESITY AND METABOLIC SYNDROME IN SMOKERS: A CROSS-SECTIONAL STUDY
}

\author{
SIGARA İÇENLERDE DİYET YAĞ İÇERİĞİNIN OBEZITTE VE METABOLİK SENDROM \\ ÜZERINE OLAN ETKİSININ İNCELENMESİ: KESİTSEL ARAŞTIRMA
}

Reyhan BİLİCİ SALMAN ${ }^{1}$, Tülay OMMA², Dilek YAPAR ${ }^{3}$, Ülper SUNU ${ }^{4}$, Emrah SALMAN ${ }^{5}$, Gül GÜRSOY1, Neşe ERSÖZ GÜLÇELİK

\begin{abstract}
AIM: To investigate the relationship between dietary fat content and obesity and markers of metabolic syndrome in smokers and non-smokers.
\end{abstract}

METHODS: 211 participants were enrolled and anthropometric measures were recorded. Food consumption was assessed through the 24-hour dietary recall method and the amount of fat consumed by a single dietician is calculated as a low-fat diet and high-fat diet.

RESULTS: Smokers with high-fat diets were younger than those with low-fat diets $(p<0.001)$. When the WHR of the smokers was compared, it was found that it was higher among women with a lowfat diet compared to high-fat diet $(\mathrm{p}=0.03)$. Fasting blood sugar, Hs$\mathrm{CRP}$, and systolic blood pressure was lower in patients with a highfat diet compared to smokers with a low-fat diet $(\mathrm{p}=0.01, \mathrm{p}=0.02$, $\mathrm{p}=0.03$, respectively) In our study, smoking was associated with an increased risk of dyslipidemia (Risk Ratio $=2.76$ (CI 95\% 1.23-6.56), $\mathrm{p}=0.01)$. Co-existence of smoking and a high-fat diet decreased the risk of dyslipidemia (Risk Ratio=0.72 (CI 95\% 0.70-0.74), p=0.01).

CONCLUSION: In addition to the current literature, our study showed that there was no relationship between a high-fat diet and components of MetS such as obesity, DM, HT, and dyslipidemia. Only being smoker was associated with an increased risk of dyslipidemia but a high-fat diet decreased the risk of dyslipidemia in the smoker.

Keywords: Smoking, High-fat diet, Metabolic Syndrome

\section{ÖZET}

AMAÇ: Sigara içen ve içmeyenlerde diyet yağ içeriğinin obezite ve metabolik sendrom markerları ile ilişkisinin incelenmesi

YÖNTEM: 211 katılımcı alındı ve antropometrik ölçümleri kaydedildi. 24 saatlik diyet hatırlama metodu ile besin tüketimi sorgulandı ve yağ miktarı tek bir diyetisyen tarafından düşük ve yüksek yağlı diyet olarak hesaplandı.

BULGULAR: Yüksek yağlı diyet ile beslenen sigara içicileri düșük yağlı diyet ile beslenenlere göre daha gençti $(p<0,001)$. Sigara içenlerde bel kalça oranları karşılaştırıldığında, kadınlarda düşük yağlı diyet ile beslenenlerde yüksek yağlı diyet ile beslenenlere göre daha yüksekti $(\mathrm{p}=0,03)$.Sigara içenlerde yüksek yağlı diyet ile beslenenlerde düşük yağlı diyet ile beslenenlere göre açlık kan şekeri, Hs-CRP ve sistolik kan basıncı daha düşüktü ( $\mathrm{p}=0,01, \mathrm{p}=0,02, \mathrm{p}=0,03$, sırasıyla). Bizim çalışmamızda sigara dislipidemi riskinde artış ile ilișkiliydi (Risk Oranı=2,76 (\%95 GA 1,23-6,56), p=0,01).

SONUÇ: Güncel literatüre ek olarak bizim çalışmamızda yüksek yağlı diyet ile metabolik sendrom komponentleri örneğin obezite, DM, HT ve dislipidemi arasında ilişki bulunmamıștır. Sadece sigara içimi dislipidemi riskini azaltırken, yüksek yağlı diyet ile beslenen sigara içicilerinde dislipidemi riski azalmıștır.

Anahtar sözcükler: Sigara, Yüksek yağlı diyet, Metabolik Sendrom

${ }^{1}$ Ankara Training and Research Hospital, Internal Medicine Department, Ankara, Turkey.

${ }^{2}$ Ankara Training and Research Hospital, Endocrinology Department, Ankara, Turkey.

${ }^{3}$ Gazi University School of Medicine, Public Health Department, Ankara, Turkey.

${ }^{4}$ Ankara Training and Research Hospital, Dietetics Department, Ankara, Turkey.

${ }^{5}$ Ankara City Hospital, Microbiology Department, Basic Immunology, Ankara, Turkey.

Geliş Tarihi / Submitted : Ocak 2020 / January 2020

Kabul Tarihi / Accepted : Nisan 2019 / April 2020

\author{
Sorumlu Yazar / Corresponding Author: \\ Reyhan BİLICII SALMAN \\ Ankara Training and Research Hospital, Internal Medicine Department, Ankara, Turkey \\ Phone: +903123054077 \\ Gsm: +905549470143 \\ Fax: +903122213202 \\ E-mail: reyhan.emrahsalman@gmail.com
}

\section{Yazar Bilgileri /Author Information:}

Reyhan BİLİCI SALMAN (ORCID: 0000-0002-2523-1695),

Tülay OMMA (ORCID: 0000-0002-2557-9499) E-mail: uzmanbilim@hotmail.com, Dilek YAPAR (ORCID: 0000-0001-7656-1152) E-mail: dilekceliker@outlook.com, Ülper SUNU (ORCID: 0000-0003-2782-2197) E-mail: ulperkurt@gmail.com, Emrah SALMAN (ORCID: 0000-0002-5293-0803) E-mail: emrahsalman85@hotmail.com, Gül GÜRSOY (ORCID: 0000-0003-2647-694X) E-mail: gulgursoyyener@yahoo.com, Neşe ERSÖZ GÜLÇELIK (ORCID: 0000-0001-8212-5712) E-mail: neseersoz@hotmail.com 


\section{INTRODUCTION}

Metabolic syndrome (MetS),obesity and smoking are growing public health concern worldwide. Despite efforts to give up smoking, many smokers avoid quit smoking because of weight control. MetS (1) is a common condition which has considerable impact on the global incidence of type 2 diabetes and cardiovascular disease. MetS is becoming more frequent in developed countries and the frequency ofthis syndrome is increasing among smokers, sedentary people and the populations of low socioeconomic status $(2,3)$. The aetiology of MetS is the result of a complex interaction between genetic, metabolic, and environmental factors, including dietary habits (the quality and quantity of dietary fat probably have a role as well) (4). Traditionally, people have subscribed to the belief that fat contains the most calories per gram (as compared to carbohydrates and proteins). On the other hand, the relation between dietary fat content and obesityor metabolic syndrome have shown inconsistent results (5).

There is evidence that nicotine plays a crucial role in regulating appetite (6) but the impact of nicotine on body weight regulation in obesity-prone and obesity-resistant populations consuming calorie-dense diets is unknown. Previous findings from studies on mice have shown that nicotine plus a high-fat diet induces intramyocellular lipid accumulation and mitochondrial abnormalities in obese mice (7).

Nicotine and obesity have long been a question of great interest in a widerange of fields. In the literature on obesity, the relative importance of nicotine has been subject to considerable discussion. While some research has been carried out on the association between obesity and smoking in mice, no single study exist. The aim of the study is to investigate the relationship between dietary fat content and adiposity and markers of metabolic syndrome in smokers and non-smokers.

\section{MATERIAL AND METHODS Study Population}

This cross-sectional study included 211 patients who admitted to the Department of Internal Medicine, Endocrinology and Metabolism Clinic between June 2014 and April 2015 consecutively. Only adults aged between 18 and 65 years were included in the study. Exclusion criteria were the presence of chronic kidney disease, hepatic dysfunction, rheumatological diseases or chronic infections. The presence of these diseases were confirmed by biochemical analysis. All subjects were interviewed using a lifestyle questionnaire, which included information about alcohol and cigarette consumption and physical activity. Participants were classified as current and never smokers based on the self-reported smoking habits. Frequency of alcohol consumption was measured by a food frequency questionnaire. Height (m), weight $(\mathrm{kg})$,waist and hip circumference $(\mathrm{cm})$ and blood pressure $(\mathrm{mmHg})$ were measured by an investigator. Systolic and diastolic blood pressures (SBP and DBP) were measured after a 5 -min rest in a semi-sitting position with a sphygmomanometer. Body mass index (BMI) was calculated as the weight in kilograms divided by the square of the height in meters. Obesity was defined as a BMI of $\geq 30 \mathrm{~kg} / \mathrm{m} 2$. The local ethics committee (Ankara Training and Research Hospital ethics committee, approved the study and waived the requirement for informed consent from the study participants (Meeting date and number 02/04/2014-543/4545). All procedures/data collection was done according to the Declaration of Helsinki.

\section{Nutrition Assessment}

Nutrition assessment was performed once at the time of recruitment based on the previous day's 24-hour dietary recall. Diet assessments were administered via interview by trained staff. To help participants estimate portion sizes, interviewers provided commonly used serving plates, bowls, utensils, cups, and spoons. If measurements could not be given, we recorded three sizes: small, medium, or large, and any unusual intake was noted on the recall.

Records were reviewed and analysed by a dietitian and were checked for clarification about food consumption and quantities. Analysis of the data was done to obtain a fat intake percentage. All 211 participants were divided into two groups based on fat intake:

1) a low-fat diet with $\leq 30 \%$ fat as a proportion of total energy content (57.9\% of participants), and

2) a high-fat diet with more than $30 \%$ fat as a proportion of total energy intake (42.1\% of participants).

\section{Biochemical Parameters}

A fasting venous sample was obtained after 8 hours fasting to determine: fasting blood sugar (FBS), triglycerides (TG), low-density lipoprotein cholesterol (LDL-C), total cholesterol (TC), high-density lipoprotein cholesterol (HDL-C), apolipoprotein A1 (Apo-A1), and apolipoprotein B (Apo-B) levels. FBS, TC, TG, and HDL-C concentrations were determined by enzymocalorimetric spectrophotometric method in a Roche/Hitachi molecular PP autoanalyzer. LDL-C values were computed according to the Friedewald formula. Serum apo-AI and B values were measured by the turbidimetric method (Turbitimer, Behring). Concentrations of insulin were determined by the chemiluminescent immunometric method using Diagnostic Products Corporation kits and the autoimmunanalyzer Immulite (Los Angeles, CA). High-sensitivity C-reactive protein (hsCRP) was determined by the ELISA (enzyme-linked immunosorbent assay) method. Intra- and inter-assay precision was $\mathrm{b} 5 \%$ and $\mathrm{b} 10 \%$, respectively, for all parameters. Insulin resistance was calculated using a homeostasis model of assessment $(\mathrm{HOMA})=$ blood glucose $(\mathrm{mg} / \mathrm{dl}) \times$ serum insulin $(\mu \mathrm{U} / \mathrm{ml}) / 405$.

\section{Metabolic Syndrome Definition}

IDF-2005 guidelines for MetS were observed for diagnosis of MetS, i.e., central obesity with a WC of $\geq 94 \mathrm{~cm}$ for men and $\geq 80 \mathrm{~cm}$ for women, and any two of the following four factors: 1) TG $>150 \mathrm{mg} / \mathrm{dl}$ or specific treatment for this lipid abnormality, 2) HDL-C (males $<40 \mathrm{mg} / \mathrm{dl}$ and 
females $<50 \mathrm{mg} / \mathrm{dl}$ ) or specific treatment for this lipid abnormality, 3) Hypertension $\geq 130 / 85 \mathrm{mmHg}$ (systolic blood pressure SBP/diastolic blood pressure DBP) or treatment of previously diagnosed hypertension, and 4) FBS $\geq 100 \mathrm{mg} / \mathrm{dl}$ or previously diagnosed type $2 \mathrm{DM}$.

\section{Statistical Method}

Statistical analysis was carried out using SPSS Version 21 Data were presented as mean $\pm S D$, median (interquartile range $=25$ th percentile -75 th percentile) or number (\%) unless specified. Group frequencies were compared using a chi-square test. Normal distribution of variables was confirmed by use of Kolmogorov-Smirnov and Shapiro-Wilk tests. Parametric data were analysed by a Student's t-test and non-parametric data were analysed by a Mann-Whitney $U$ test and $p<0.05$ was considered statistically significant.A multiple regression analysis was carried out with age, sex, smoking, and a high-fat diet as independent variables and metabolic syndrome or its components as dependent variables.

\section{RESULTS}

We enrolled 211 participants comprising 104 smokers and 107 non-smokers. The mean age was $46 \pm 11,6$ years in smokers. The mean BMI of the smokers was $30,7 \pm 25,1$ $\mathrm{kg} / \mathrm{m} 2$. There was a statistically significant difference between the smoker and non-smoker groups in terms of Apo-B ( $\mathrm{p}=0.02)$ and systolic blood pressure $(\mathrm{p}=0.05)$. There was no statistically significant difference between the smoker and non-smoker in terms of waist-hip ratio values. There was no difference in terms of other parameters between the groups (Table 1). Related to exercise status, $16 \%$ of smokers $(n=18)$ and $19 \%(n=20)$ of non-smokers regularly exercised and there was no significant difference in that regard $(\mathrm{p}=0.72)$.

Smokers with high-fat diets were younger than those with low-fat diets $(\mathrm{p}<0.001)$. When the WHR of the lowfat diet and high-fat diet smokers was compared, it was found that it was higher among women with a low-fat diet compared to other groups $(p=0.03)$. Fasting blood sugar, Hs-CRP, and systolic blood pressure was lower in patients with a high-fat diet compared to smokers with a low-fat diet $(\mathrm{p}=0.01, \mathrm{p}=0.02, \mathrm{p}=0.03$, respectively). There was no difference in terms of other parameters between the groups (Table 2). Although HDL-C was found to be low in non-smokers with a high-fat diet, their fasting insulin levels were higher compared to other non-smokers with a low-fat diet (with $p$ values of 0.05 and 0.04 , respectively). There was no difference in terms of other parameters between the groups (Table 3). Multiple logistic regression analysis with MetS, obesity, dyslipidemia, hypertension or DM as dependent variables and smoking, high-fat diet, or smoking+high-fat diet as independent variables are given in Table 4. Data have been adjusted for age and sex. Except for dyslipidemia age or sex was related to metabolic syndrome contents. In summary, for the informants in this study, smoking was associated with an increased risk of dyslipidemia (Risk Ratio=2.76 (CI 95\% 1.23-6.56), p=0.01). Smoking and a high-fat diet decreased the risk of dyslipidemia (Risk Ratio=0.72 (CI 95\% 0.70-0.74), p=0.01).

Table 1 Clinical and metabolic characteristics of smoking and non-smoking subjects

\begin{tabular}{|l|c|c|c|}
\hline & Smoker & Non -Smoker & P \\
\hline n(F/M) & $104(53 / 51)$ & $107(59 / 48)$ & 0.64 \\
\hline Age (years) & $46 \pm 11.6$ & $46.9 \pm 16.1$ & 0.57 \\
\hline BMI (kg/m2) & $30.7 \pm 25.1$ & $29.3 \pm 5.5$ & 0.92 \\
\hline WHR & & & 0.99 \\
\hline Men & $0.95 \pm 0.09$ & $0.95 \pm 0.09$ & 0.85 \\
\hline Women & $0.87 \pm 0.07$ & $0.86 \pm 0.10$ & 0.11 \\
\hline Fasting plasma glucose (mg/dl)* & $98.5(86.5-125.5)$ & $98(89-125)$ & 0.18 \\
\hline Fasting insulin (uIU/ml)* & $6(3.45-8.75)$ & $6.91(4.1-11.4)$ & 0.10 \\
\hline HOMA-IR & $2.08 \pm 0.20$ & $2.57 \pm 0.34$ & 0.25 \\
\hline Cholesterol (mg/dL) & $209.8 \pm 48.6$ & $199.5 \pm 43.7$ & 0.81 \\
\hline HDL cholesterol (mg/dL) & $44 \pm 10.7$ & $45.8 \pm 12.1$ & 0.10 \\
\hline Triglycerides (mg/dL) & $166 \pm 109.3$ & $162.2 \pm 43.7$ & 0.40 \\
\hline LDL cholesterol (mg/dL) & $131.8 \pm 40.2$ & $123.2 \pm 36.5$ & $\mathbf{0 . 0 2}$ \\
\hline Apo-A1 (mg/dL) & $1227 \pm 256$ & $1255.9 \pm 229.1$ & 0.52 \\
\hline Apo-B (mg/dL) & $975.3 \pm 258.5$ & $897.4 \pm 225.2$ & $\mathbf{0 . 0 5}$ \\
\hline Hs-CRP (mg/L) & $2.74(1.14-5.93)$ & $2.57(1.04-6.19)$ & \\
\hline Systolic blood pressure (mm Hg) & $117.8 \pm 14.7$ & $121.9 \pm 15$ & \\
\hline
\end{tabular}

Data is given as mean (standard deviation) or ${ }^{\star}$ median (25-75 p). BMI: Body Mass Index WHR: Waist to Hip Ratio HOMA-IR: Homeostatic Model Assessment of Insulin Resistance FBG: Fasting Blood Glucose LDL-C: Low Density Lipoprotein Cholesterol HDL-C: High Density Lipoprotein Cholesterol Apo-A1: Apolipoprotein B Apo-B: Apolipoprotein B High sensitivity C-reactive protein (Hs-CRP) 
Table 2 Clinical and metabolic characteristics of smokers with low and high-fat diets

\begin{tabular}{|c|c|c|c|}
\hline & LFD & HFD & $\mathbf{P}$ \\
\hline Gender (F/M) & $64(33 / 31)$ & $40(20 / 20)$ & \\
\hline Age (years) & $49.1 \pm 11.5$ & $41.0 \pm 9.9$ & $<0.001$ \\
\hline BMI (kg/m2) & $28.1 \pm 5.2$ & $28.6 \pm 4.6$ & 0.66 \\
\hline \multicolumn{4}{|l|}{ WHR } \\
\hline Men & $0.96 \pm 0.10$ & $0.95 \pm 0.10$ & 0.78 \\
\hline Women & $0.90 \pm 0.08$ & $0.85 \pm 0.07$ & 0.03 \\
\hline Fasting plasma glucose $(\mathrm{mg} / \mathrm{dl})^{\star}$ & $105(92-146)$ & $90(81-107)$ & 0.01 \\
\hline Fasting insulin $(\mathrm{uIU} / \mathrm{ml})^{*}$ & $5.60(3.80-8.80)$ & $6.00(3.25-8.55)$ & 0.99 \\
\hline HOMA-IR ${ }^{*}$ & $1.77(1-2.43)$ & $1.40(0.68-2.55)$ & 0.33 \\
\hline Cholesterol (mg/dL) & $210.8 \pm 57.6$ & $199 \pm 37$ & 0.29 \\
\hline HDL cholesterol (mg/dL) & $44.1 \pm 10.9$ & $43.8 \pm 10.3$ & 0.87 \\
\hline Triglycerides $(\mathrm{mg} / \mathrm{dL})^{*}$ & $150(95-230)$ & $123(85.5-189)$ & 0.17 \\
\hline LDL cholesterol (mg/dL) & $134.2 \pm 45.3$ & $128.2 \pm 30.5$ & 0.46 \\
\hline Apo-A1 (mg/dL) & $1208 \pm 250$ & $1257 \pm 264$ & 0.36 \\
\hline Apo-B (mg/dL) & $1001 \pm 270$ & $934 \pm 236$ & 0.21 \\
\hline Hs-CRP $(\mathrm{mg} / \mathrm{L})^{*}$ & $3.9(1.85-8.20)$ & $1.52(0.92-5.69)$ & 0.02 \\
\hline Systolic blood pressure (mm Hg) & $120.2 \pm 14.6$ & $114 \pm 14.2$ & 0.03 \\
\hline
\end{tabular}

Data is given as mean (standard deviation) or ${ }^{\star}$ median (25-75 p). BMI: Body Mass Index WHR: Waist to Hip Ratio HOMA-IR: Homeostatic Model Assessment of Insulin Resistance FBG: Fasting Blood Glucose LDL-C: Low Density Lipoprotein Cholesterol HDL-C: High Density Lipoprotein Cholesterol Apo-A1: Apolipoprotein B Apo-B: Apolipoprotein B High sensitivity C-reactive protein (Hs-CRP)

Table 3 Clinical and metabolic characteristics of non-smoking subjects with low- and high-fat diets

\begin{tabular}{|c|c|c|c|}
\hline & LFD & HFD & $\mathbf{P}$ \\
\hline Gender (F/M) & $58(35 / 23)$ & $49(24 / 25)$ & \\
\hline Age (years) & $49.0 \pm 16$ & $44.3 \pm 16.1$ & 0.13 \\
\hline BMI $(\mathrm{kg} / \mathrm{m} 2)$ & $29.6 \pm 5.5$ & $28.9 \pm 5.5$ & 0.51 \\
\hline \multicolumn{4}{|l|}{ WHR } \\
\hline Men & $0.98 \pm 0.10$ & $0.93 \pm 0.08$ & 0.099 \\
\hline Women & $0.86 \pm 0.08$ & $0.87 \pm 0.13$ & 0.849 \\
\hline Fasting plasma glucose $(\mathrm{mg} / \mathrm{dl})^{\star}$ & $99(89-122)$ & $95(89-136)$ & 0.92 \\
\hline Fasting insulin $(\mathrm{uIU} / \mathrm{ml})^{*}$ & $5.80(3.43-9.80)$ & $9.80(5.14-13.40)$ & 0.04 \\
\hline HOMA-IR* & $1.50(0.87-2.29)$ & $2.47(1.32-3.42)$ & 0.30 \\
\hline Cholesterol (mg/dL) & $203 \pm 45$ & $195 \pm 42$ & 0.34 \\
\hline HDL cholesterol $(\mathrm{mg} / \mathrm{dL})$ & $47.9 \pm 13.6$ & $43.3 \pm 9.7$ & 0.05 \\
\hline Triglycerides $(\mathrm{mg} / \mathrm{dL})^{*}$ & $139.5(87-192)$ & $124(100-193.5)$ & 0.92 \\
\hline LDL cholesterol $(\mathrm{mg} / \mathrm{dL})$ & $122.4 \pm 36.3$ & $124.2 \pm 37.1$ & 0.80 \\
\hline Apo-A1 (mg/dL) & $1273 \pm 245$ & $1238 \pm 210$ & 0.44 \\
\hline Apo-B (mg/dL) & $895 \pm 236$ & $899 \pm 212$ & 0.94 \\
\hline Hs-CRP $(\mathrm{mg} / \mathrm{L})^{*}$ & $2.70(1.20-7.3)$ & $2.42(0.76-5.61)$ & 0.30 \\
\hline Systolic blood pressure (mm Hg) & $119 \pm 16$ & $124 \pm 12$ & 0.13 \\
\hline
\end{tabular}

Data is given as mean (standard deviation) or ${ }^{\star}$ median (25-75 p). BMI: Body Mass Index WHR: Waist to Hip Ratio HOMA-IR: Homeostatic Model Assessment of Insulin Resistance FBG: Fasting Blood Glucose LDL-C: Low Density Lipoprotein Cholesterol HDL-C: High Density Lipoprotein Cholesterol Apo-A1: Apolipoprotein B Apo-B: ApolipoproteinB High sensitivity C-reactive protein (Hs-CRP) 
Table 4. Multiple logistic regression analysis with MetS, obesity, dyslipidemia, hypertension or DM as dependent variables and smoking, high-fat diet, or smoking+high-fat diet as independent variables (for subjects with complete data)

\begin{tabular}{|c|c|c|}
\hline & \multicolumn{2}{|c|}{ Dependent variable: MetS, $n=99$} \\
\hline Independent variable & OR & $\mathbf{P}$ \\
\hline Smoking & $0.95(0.44-2.05)$ & 0.91 \\
\hline HFD & $1.06(0.45-2.47)$ & 0.88 \\
\hline \multirow[t]{2}{*}{ Smoking-HFD } & $0.87(0.26-2.84)$ & 0.81 \\
\hline & \multicolumn{2}{|c|}{ Dependent variable: Obesity, $n=145$} \\
\hline Independent variable & OR & $\mathbf{P}$ \\
\hline Smoking & $0.57(0.23-1.42)$ & 0.23 \\
\hline HFD & $0.59(0.22-1.55)$ & 0.29 \\
\hline \multirow[t]{2}{*}{ Smoking-HFD } & $1.84(0.49-6.87)$ & 0.36 \\
\hline & \multicolumn{2}{|c|}{ Dependent variable: Dyslipidemia, $n=139$} \\
\hline Independent variable & OR & $\mathbf{P}$ \\
\hline Smoking & $2.76(1.23-6.56)$ & 0.01 \\
\hline HFD & $1.48(0.65-3.32)$ & 0.34 \\
\hline \multirow[t]{2}{*}{ Smoking-HFD } & $0.72(0.70-0.74)$ & 0.01 \\
\hline & \multicolumn{2}{|c|}{ Dependent variable: $\mathrm{HT}, \mathrm{n}=54$} \\
\hline Independent variable & OR & $\mathbf{P}$ \\
\hline Smoking & $0.86(0.37-2.01)$ & 0.74 \\
\hline HFD & $0.54(0.19-1.48)$ & 0.23 \\
\hline \multirow[t]{2}{*}{ Smoking-HFD } & $1.16(0.25-5.30)$ & 0.84 \\
\hline & \multicolumn{2}{|c|}{ Dependent variable: $\mathrm{DM}, \mathrm{n}=\mathbf{5 7}$} \\
\hline Independentvariable & OR & $\mathbf{P}$ \\
\hline Smoking & $1.48(0.63-3.44)$ & 0.36 \\
\hline HFD & $1.57(0.61-4.07)$ & 0.34 \\
\hline Smoking-HFD & $0.31(0.07-1.32)$ & 0.11 \\
\hline
\end{tabular}

MetS: Metabolic Syndrome HT: Hypertension DM: Diabetes Mellitus HFD: High Fat Diet

Adjusted for age and sex. ${ }^{*}$ Metabolic syndrome was defined based on IDF-2005 guidelines

\section{DISCUSSION}

Few studies have been done in the field of a high-fat diet with nicotine and obesity in mice but there is no study in human in this area. It was claimed in a study that, nicotine suppresses appetite and prevents weight gain(8), which is a factor impacting smoking initiation and failure-to-quit, particularly among obese smokers. This paper aimedto provide answers to several outstanding questions relating to the relationship between smoking and dietary fat on obesity and metabolic syndrome. In this study, we showed that only being smoker was associated with an increased risk of dyslipidemia but a high-fat diet decreased the risk of dyslipidemia in the smoker. However, no significant association was found between a high-fat diet and obesity or MetS in smokers.

Macrophages located in white adipose tissue express $\alpha 7$ $\mathrm{nAChR}$, that when activated by nicotine inhibit the secretion of pro-inflammatory cytokines, limiting the inflammatory state of obese smokers and helping to reduce body weight
(9). Nicotine stimulates the secretion of adiponectin and leptin from white adipose tissues, which leads to reduced food intake and increased metabolism (effects that are both observed in smokers) (10). On the other hand, chronic cigarette smoking has been associated with elevated circulating levels of inflammatory cytokines such as TNF- $\alpha$ and IL-6 that are known to lead to the development of insulin resistance usually linked to obesity $(11,12)$. Two papers also showed that abdominal obesity was higher in long-term smokers than non-smokers $(13,14)$.

Although earlier data indicate that a high-fat diet contributes to obesity and cardiometabolic risk, a recent review rejects this hypothesis and suggests that it is inversely associated with obesity risk (15). The relationship between a high-fat diet and the incidence of DM is unclear. Three out of six studies reported that DM incidence is inversely associated with a high-fat diet $(16,17)$ while the remainder found evidence that LFD may lower the risk of DM (17-19). In one of these latter studies, the incidence of 
DM was associated neither with high nor with the low-fat dietary intake (20).

We found smokers with high-fat diets were younger than those with low-fat diets. This situation can be explained by a common belief of nicotine leading weight loss in young, however recently a research showed that there were no differences in weight loss outcomes between never smokers, ex-smokers and current smokers within either condition (21). Another study in 2018 claimed that smoking status was not significantly associated with weight loss (22). Smoker women WHR of the low-fat diet was higher than high-fat diet smokers but there was no statistical difference in WHR for men. Fasting blood sugar, Hs-CRP, and systolic blood pressure was lower in patients with a high-fat diet compared to smokers with a low-fat diet in our study. Otherwise, HDL-C was found to be low in non-smokers with a high-fat diet, their fasting insulin levels were higher compared to other nonsmokers with a low-fat diet. Contrary to global belief our study demonstrated that a low-fat diet was not related to metabolic parameters. In addition to the current literature, our study showed that there was no relationship between a high-fat diet and components of MetS such as obesity, DM, HT, and dyslipidemia. Only being smoker was associated with an increased risk of dyslipidemia but a high-fat diet decreased the risk of dyslipidemia in the smoker.

Recent studies in animals showed that nicotine reduced body weight by decreasing food intake and by increasing brown adipose tissue thermogenesis in both low-fat diet and diet-induced obese rats (23). This data suggests that nicotine diminishes body weight and improves metabolic disorders linked to diet-induced obesity. However, there are reports in rodents that nicotine combined with a high-fat diet induces metabolic disorders (with some studies showing that a decrease in body weight occurs in this situation). Further studies claim that the cause of the relationship between dietary intake and metabolic disorders is dairy carbohydrate intake (such as fructose).

Consequently, the effect of nicotine on food intake and metabolism is complex. It acts at different levels, both centrally and peripherally, to regulate multiple hormones, neuropeptides, and their receptors to modify energy expenditure and feeding behaviour. Changes in the overall diet of smokers and ex-smokers mayleadto an increased incidence of diseases linked to MetS, potentially limiting the benefit of smoking cessation.

Diet was self-reported and we cannot rule out the occurrence of some recall bias. We registered only total energy and fat content and divided into two groups based on fat intake. Quality of dietary fat and insulin resistance or weight loss is inconsistent in the literature but we don't know its effect on obesity or MetS.

To our knowledge, this is the first study that has reported a relationship between dietary fat content, obesity, and MetS for smokers. Despite the evidence accumulated with regard to the action of nicotine and a high-fat diet in mice, further studies are needed to delineate the exact mechanism of nicotine-induced changes in energy expenditure and feeding behaviour in humans.

Acknowledgements :This paper was not funded by anyone. The authors declare no conflict of interest related to this work.

\section{REFERENCES}

1.)Bruce $\mathrm{KD}$, Byrne $\mathrm{CD}$. The metabolic syndrome: common origins of a multifactorial disorder. Postgraduate medical journal. 2009;85(1009):614-21.

2.)Lee E-G, Choi J-H, Kim K-E, et al. Effects of a walking program on self-management and risk factors of metabolic syndrome in older Korean adults. Journal of physical therapy science. 2014;26(1):105-9. 3.)García JB, Rentero PZ, Cánovas JM, et al. Biochemical and nutritional markers and antioxidant activity in metabolic syndrome. Endocrinología y Nutrición (English Edition). 2014;61(6):302-8.

4.)Phillips C, Lopez-Miranda J, Perez-Jimenez F, et al. Genetic and nutrient determinants of the metabolic syndrome. Current opinion in cardiology. 2006;21(3):185-93.

5.)Melanson EL, Astrup A, Donahoo WT. The relationship between dietary fat and fatty acid intake and body weight, diabetes, and the metabolic syndrome. Annals of nutrition \& metabolism. 2009;55(1-3):229-43.

6.)Stojakovic A, Espinosa EP, Farhad OT, et al. Effects of nicotine on homeostatic and hedonic components of food intake. The Journal of endocrinology. 2017;235(1):R13-r31.

7.)Friedman TC, Sinha-Hikim I, Parveen M, et al. Additive effects of nicotine and high-fat diet on hepatic steatosis in male mice. Endocrinology. 2012;153(12):5809-20.

8.)Lutter M, Nestler EJ. Homeostatic and hedonic signals interact in the regulation of food intake. The Journal of nutrition. 2009;139(3):629-32. 9.) Pavlov VA, Wang $\mathrm{H}$, Czura $\mathrm{CJ}$, et al. The cholinergic antiinflammatory pathway: a missinglink in neuroimmunomodulation. Molecular medicine. 2003;9(5-8):125.

10.)Fulton $S$, Pissios $P$, Manchon RP, et al. Leptin regulation of the mesoaccumbens dopamine pathway. Neuron. 2006;51(6):811-22. 11.)Ellingsgaard $H$, Ehses JA, Hammar EB, et al. Interleukin-6 regulates pancreatic a-cell mass expansion. Proceedings of the national academy of sciences. 2008;105(35):13163-8.

12.) Wu Y, Song P, Zhang W, et al. Activation of AMPKa2 in adipocytes is essential for nicotine-induced insulin resistance in vivo. Nature medicine. 2015;21(4):373.

13.) Kim JH, Shim KW, Yoon YS,et al. Cigarette smoking increases abdominal and visceral obesity but not overall fatness: an observational study. PloS one. 2012;7(9):e45815.

14.)Clair C, Chiolero A, Faeh D, et al. Dose-dependent positive association between cigarette smoking, abdominal obesity and body fat: cross-sectional data from a population-based survey. BMC public health. 2011;11(1):23.

15.)Kratz M, Baars T, Guyenet $S$. The relationship between highfat dairy consumption and obesity, cardiovascular, and metabolic disease. European journal of nutrition. 2013;52(1):1-24.

16.)Mozaffarian $\mathrm{D}$, Cao $\mathrm{H}$, King IB, et al. Trans-palmitoleic acid, metabolic risk factors, and new-onset diabetes in US adults: a cohort study. Annals of internal medicine. 2010;153(12):790-9.

17.)Hodge AM, English DR, O'dea K, et al. Plasma phospholipid and dietary fatty acids as predictors of type 2 diabetes: interpreting the role of linoleic acid-. The American journal of clinical nutrition. 2007;86(1):189-97.

18.)Mossavar-Rahmani Yasmin Phillips Lawrence S. Shikany James M. Tinker Lesley F. A Diet High in Low-Fat Dairy Products Lowers Diabetes Risk in Postmenopausal Women, 2. The Journal of nutrition. 
2011;141(11):1969-74.

19.)Choi HK, Willett WC, Stampfer MJ, et al. Dairy consumption and risk of type 2 diabetes mellitus in men: a prospective study. Archives of internal medicine. 2005;165(9):997-1003.

20.)Soedamah-Muthu SS, Masset G, Verberne L, et al. Consumption of dairy products and associations with incident diabetes, CHD and mortality in the Whitehall II study. British Journal of Nutrition. 2013;109(4):718-26.

21.)Murphy CM, Rohsenow DJ, Johnson KC, et al. Smoking and weight loss among smokers with overweight and obesity in Look AHEAD. Health Psychology. 2018;37(5):399.

22.)Kowalewski PK, Olszewski R, Walędziak MS, et al. Cigarette smoking and its impact on weight loss after bariatric surgery: A single center, retrospective study. Surgery for obesity and related diseases : official journal of the American Society for Bariatric Surgery. 2018;14(8):1163-6. 23.)Seoane-Collazo P, de Morentin PBM, Fernø J, et al. Nicotine improves obesity and hepatic steatosis and ER stress in dietinduced obese male rats. Endocrinology. 2014;155(5):1679-89.

Ankara Eğt. Arş. Hast. Derg. (Med. J. Ankara Tr. Res. Hosp.), 2020 ; 53(1) : S20-S26

The local ethics committee (Ankara Training and Research Hospital ethics committee, approved the study and waived the requirement for informed consent from the study participants (Meeting date and number 02/04/2014-543/4545). 